\title{
Llegué a Saramago tarde
}

\author{
Cristopher Montero Corrales \\ Premio Nacional Aquileo J. Echeverría 2018, en la categoría \\ de Cuento con la obra, Los cerdos comen bellotas.
}

$\Delta$ 1 primer intento, me perdí. "El hombre que conduce la camioneta se llama Cipriano Algor, es alfarero de profesión y tiene sesenta y cuatro años, aunque a simple vista aparenta menos edad". A mí qué carajo me importaba la vida de un conductor que de profesión era alfarero y aparentaba menos edad. Así que dejé el libro en mi biblioteca, sin más. Algunas veces lo intenté pero siempre me perdía en ese primer párrafo. Quien me lo regaló me dijo "tiene una relación con la caverna de Platón puede ser que te guste". Algo tan inexacto no puede motivar.

(Tantas cosas tienen relación con el mito de la caverna de Platón; justo por eso es una alegoría.)

No fue eufórica, no invitaba a leer una recomendación tan desabrida. Si me hubiera dicho: -Mirá, te lo regalo porque experimenta con la mayúscula para establecer diálogos entre personajes.

-En serio, qué interesante.

Lo dudo. En ese momento no lo hubiera entendido. Seis años después, de ese primer intento; Irina me cuenta que es su escritor favorito, Tengo La caverna en mi biblioteca, Ah, es el primero donde experimenta con mayúsculas para los diálogos entre personajes, le da una fluidez, En serio, qué interesante.

Y pude entenderlo. Y usé un pétalo rosa como separador de lectura. Y leí cada hoja sabiendo que nuestros cerebros compartirían otro texto; mil doscientas cincuenta y ocho hojas hasta el momento. Eso debía significar algo.

Dijo él, Querés que te cuente, por fin, por qué guardo el primer pétalo que se desprendió de la rosa que me regalaste en mi cumpleaños 33. Dijo ella, Por favor. Dijo él, Porque se me parece a tu ano. Dijo ella, Qué. Dijo él, Porque se me parece a tu ano, ese pétalo rosa de que a su vez me mira, tiene un pliegue, como si una parte sutil y delgada se extendiera sobre sí misma en el lado izquierdo, una sofisticación que cayó hasta mi dedo pulgar, balanceándose de un lado para otro, y como se apoyó tan lúdicamente luego se llevó a mis labios: mi único apoyo en el mundo era ese pétalo hipnótico, su mirada encendida.

(Todo lo que estaba del ano para adentro era ella, todo lo que estaba del ano para afuera era ella, ahí la novedad. Ese era el lazo antiguo que reestablecíamos.) 
